\title{
Praktik Belajar Mengajar Online Selama Pandemi Covid-19
}

\author{
Siti Alfiyah ${ }^{1}{ }^{凶}$, Muthmainah $^{2}$ \\ Pendidikan Anak Usia Dini, Universitas Negeri Yogyakarta(1) \\ DOI: $10.31004 /$ obsesi.v6i4.2228
}

\begin{abstract}
Abstrak
Praktik belajar mengajar online akan terus dilakukan mengingat belum tuntasnya wabah Covid-19 di Indonesia. Studi literatur ini bertujuan untuk memberikan gambaran bagaimana praktik belajar mengajar online yang efektif dalam menstimulasi perkembangan anak selama pandemi covid-19. Metode menggunakan studi literatur. Teknik pengumpulan data dengan mengumpulkan sejumlah artikel maupun jurnal nasional maupun internasional yang berkaitan dengan masalah dan tujuan penelitian. Teknik analisis data meliputi pengumpulan sumber data, reduksi data, dan penarikan kesimpulan. Hasil dari penelitian ini guru, orangtua dan anak dapat melaksanakan proses pembelajaran melalui beberapa cara, meliputi pembelajaran melalui whatsApp group, home visit, zoom dan google classroom, dan pembelajaran melalui tayangan televisi saluran TVRI. Hasil penelitian ini dapat digunakan sebagai bahan referensi atau acuan dalam mengevaluasi praktik belajar mengajar online, sehingga hambatan yang terjadi pada pembelajaran daring dapat diatasi oleh orang tua, guru, atau stakeholder di dalam dunia pendidikan.
\end{abstract}

Kata Kunci: Praktik belajar mengajar online; covid-19; anak usia dini

\begin{abstract}
Online teaching and learning practices will continue to be carried out considering the COVID19 outbreak in Indonesia has not yet been completed. This literature study aims to provide an overview of how effective online teaching and learning practices are in stimulating children's growth and development during the COVID-19 pandemic. The method used is a literature study. Data collection techniques by collecting a number of articles and national and international journals related to the problem and research objectives. Data analysis techniques include collecting data sources, data reduction, and drawing conclusions. The results of this study are teachers, parents and children can carry out the learning process in several ways, including learning through WhatsApp groups, home visits, zoom and google classroom, and learning through TVRI channel television shows. The results of this study can be used as reference material or reference in evaluating online teaching and learning practices, so that the obstacles that occur in online learning can be overcome by parents, teachers, or stakeholders in the world of education.
\end{abstract}

Keywords: Online teaching and learning practice; covid-19; early childhood

Copyright (c) 2022 Siti Alfiyah, Muthmainah

$\triangle$ Corresponding author: Siti Alfiyah

Email Address: sitialfiyah958@gmail.com (Yogyakarta, Indoenesia)

Received 3 November 2021, Accepted 4 February 2022, Published 4 February 2022 


\section{PENDAHULUAN}

Pandemi COVID-19 memberikan dampak pada banyak elemen kehidupan. Pandemi ini telah mempengaruhi semua aspek kehidupan manusia termasuk bisnis, penelitian, pendidikan, kesehatan, ekonomi, olahraga, transportasi, ibadah, interaksi sosial, politik, pemerintahan, dan hiburan (Orfan \& Elmyar, 2020). Pemerintah pusat mengeluarkan kebijakan untuk membatasi kegiatan di luar rumah sebagai upaya mencegah meluasnya penularan covid-19. Kebijakan-kebijakan yang dikeluarkan untuk membatasi penyebaran covid-19 berdampak pada berbagai bidang diseluruh dunia khususnya pendidikan di Indonesia. Pandemi covid-19 mendesak pengujian pendidikan jarak jauh hampir yang belum pernah dilakukan secara serempak sebelumnya (Sun et al., 2020) bagi semua elemen pendidikan yakni peserta didik, guru hingga orang tua. Mengingat pada masa pandemic, waktu, lokasi dan jarak menjadi permasalahan besar saat ini (Kusuma \& Hamidah, 2020). Sehingga pembelajaran jarak jauh menjadi solusi untuk mengatasi kesulitan dalam melaksanakan pembelajaran secara tatap muka langsung. Ini memberikan tantangan kepada semua elemen dan jenjang pendidikan untuk mempertahankan kelas tetap aktif meskipun sekolah telah ditutup.

Pandemi Covid-19 telah menimbulkan tantangan dalam dunia pendidikan sehingga mengharuskan para guru untuk beradaptasi dengan pengajaran baru (König et al., 2020) yaitu pembelajaran yang dilangsungkan secara online. Pembelajaran online merupakan pembelajaran yang menggunakan jaringan internet dengan aksesibilitas, konektivitas, fleksibilitas yang dapat memunculkan jenis-jenis interaksi pembelajaran (Moore et al., 2011). Menurut Widiastuti et al. (2020) mengartikan pembelajaran online dengan penggunaan teknologi dan media elektronik dalam menyampaikan, mendukung, dan meningkatkan pembelajaran dan pengajaran dan melibatkan komunikasi antara pelajar dan guru yang memanfaatkan konten online. Pembelajaran online merupakan konsep atau cara penyampaian pengetahuan atau Pendidikan kepada peserta didik melalui interaksi digital (Thanji \& Vasantha, 2016).

Pembelajaran online bertujuan untuk memfasilitasi pendidikan anak di masa covid-19 melalui perangkat digital yang dilaksanakan oleh guru dengan peserta didik di rumah masing-masing sehingga pembelajaran tetap berlangsung dengan situasi pandemic (Dong et al., 2020). Penggabungan teknologi telah mengubah proses belajar mengajar dengan sistem pembelajaran online, proses belajar dapat dilakukan tanpa mengenal waktu dan tempat (Chang et al., 2021). Pembelajaran daring memberikan metode pembelajaran yang efektif, seperti dalam berlatih dengan adanya umpan balik terkait, menggabungkan kolaborasi kegiatan belajar mandiri, personalisasi pembelajaran berdasarkan kebutuhan siswa yang menggunakan simulasi, dan permainan membantu perkembangan teknologi yang memungkinkan pembelajaran di dalam kelas dapat diakses di rumah maupun di lingkungan sekitarnya (Djaswadi, 2021a).

Penerapan pembelajaran online pada semua elemen Pendidikan bukan tanpa tantangan. Pembelajaran online membutuhkan banyak waktu dan komitmen. Para pendidik harus lebih kreatif mengelola proses pembelajaran online (Nurdin \& Anhusadar, 2020). Pelaksanaan pembelajaran online yang kreatif tidak mudah diterapkan oleh guru (Crawford et al., 2020), oleh karena itu perlunya pelatihan yang berkelanjutan (Hodges et al., 2020) sehingga mendukung pengembangan keterampilan mengajar guru yang efektif (Van Schagen Johnson et al., 2017) dan menjadikan pembelajaran semakin kondusif bagi peserta didik (Law, 2021). Mengingat banyaknya tuntutan-tuntutan terus-menerus ditempatkan pada siswa dan pendidik, mendorong departemen untuk menemukan cara baru dalam memberikan pengalaman belajar mandiri yang lebih personal (O'Doherty et al., 2018).

Pembelajaran online diterapkan pada institusi sekolah di seluruh Indonesia baik di kota maupun di pedesaan (Kartini, 2021) termasuk Pendidikan Anak Usia Dini. Karena kebijakan "lockdown", kegiatan belajar mengajar baik pendidikan formal maupun nonformal terhenti. Kebijakan tersebut tentunya tidak dapat memastikan semuanya akan berjalan 
sebagaimana mestinya disemua kalangan, khusus nya sekolah di pedesaan (Agus Susilo, 2013); karena sarana dan prasarana pendidikan di daerah perdalaman yang kurang memadai, kekurangan fasilitas maupun koneksi jaringan (Kartini, 2021), terutama pada pelaksanaan pembelajaran bagi anak usia dini (Suhendro, 2020a); yang merupakan masa emas (golden age) yang hanya ada sekali periode dalam kehidupannya dan tidak dapat diulang kembali (Suhendro \& Syaefudin, 2020). Oleh karena itu, pentingnya pembelajaran online harus diteliti secara mendalam agar tercapai tujuan pembelajaran anak usia dini.

Guru atau pendidik merupakan elemen penting dalam pembelajaran, mau tidak mau harus mengikuti dan menyesuaikan pembelajaran sesuai situasi masa kini (Basilaia \& Kvavadze, 2020). Pendidik profesional di era digital adalah pendidik yang mahir dan gandrung akan teknologi informasi dari berbagai aplikasi digital. Pembelajaran online akan menjadi sangat efektif jika memenuhi komponen esensial dalam pembelajaran yaitu diskursif, adaptif, interaktif dan reflektif dengan elemen-elemen yang diintegrasikan dengan lingkungan pembelajar sehingga dapat memunculkan perasaan positif bagi para pengguna (Oktavian \& Aldya, 2020). Pernyataan tersebut juga didukung dengan munculnya perangkat mobile, Web 2.0, Web 3.0 dan baru-baru ini Web 4.0 dan ledakan teknologi media sosial memberikan kesempatan bagi guru dan peserta didik untuk menciptakan pengalaman belajar mandiri kan cara baru dalam memberikan pengalaman belajar mandiri yang lebih personal (O’Doherty et al., 2018).

Pembelajaran online pada umumnya menggunakan berbagai alat dan sumber daya digital untuk memecahkan masalah dan menerapkan pendekatan baru dalam proses belajar mengajar (Eickelmann \& Gerick, 2020), seperti WhatsApps (So, 2016), Google Form, Google Drive, Youtube, Tuweb, Zoom Meeting (Anugrahana, 2020), Google Classroom, Edmodo, dan Schoology (Negara, 2018), dan Facebook maupun Instagram (Kumar \& Nanda, 2019). Pada Pendidikan anak usia dini, sumber daya digital yang umum digunakan guru dalam proses pembelajaran adalah whatsapp grup, sewaktu-waktu aplikasi zoom (Kartini, 2021), pesan teks, dan via telepon (Suhendro, 2020a).

Pembelajaran online memberikan metode pembelajaran yang efektif, dimana anak dapat berlatih belajar mandiri di rumah maupun di lingkungan sekitarnya (Djaswadi, 2021b). Selain itu, pembelajaran online menjadi solusi permasalahan keterlambatan peserta didik untuk memperoleh ilmu pengetahuan di masa Covid-19 (Herliandry et al., 2020). Namun, hasil penelitian lain menunjukkan bahwa pembelajaran daring tidak sebaik pembelajaran langsung, mayoritas siswa tidak menyukai pembelajaran daring dibandingkan dengan pembelajaran luring (Noori, 2021). Diperjelas dengan hasil penelitian Abbasi et al. (2020) bahwa pengalaman pembelajaran online tidak cukup menarik karena banyaknya keterbatasan berupa koneksi, sumber belajar, maupun kurangnya pengetahuan pendamping. Ketidakmaksimalan pembelajaran daring tentunya menimbulkan banyak permasalahan, khususnya pada anak usia dini yang notabennya membutuhkan bimbingan secara langsung (Safrizal et al., 2021).

Kendala lainnya ditemukan dari pembelajaran daring bagi siswa usia 5-6 tahun, adalah siswa usia ini masih memerlukan pendampingan secara utuh dari guru atau orang tua, namun masih banyak orang tua yang tidak memiliki smartphone untuk menunjang proses pembelajaran, dan pembelajaran daring hanya bersifat pemberian tugas oleh guru karena terbatasnya cara memberikan pemahaman terhadap peserta didik (Napitupulu et al., 2020). Sehingga sumber daya yang tidak memadai menjadi masalah dalam menjaga integritas akademik, masalah kebijakan, masalah teknis, kurangnya kepercayaan diri, dan kurangnya pengetahuan orangtua peserta didik menjadi tantangan utama dalam pelaksanaan pembelajaran daring selama pandemi covid 19 (Noori, 2021). Selain itu, masih banyak ditemukan guru yang merasa bingung menerapkan pembelajaran daring yang kreatif yang dapat menarik perhatian anak. 
Berdasarkan kondisi dan kesenjangan tersebut maka perlu dilakukan review pustaka terkait praktik belajar mengajar online selama pandemi covid-19, mengingat pembelajaran online akan terus dilakukan mengingat belum tuntasnya wabah Covid-19 di Indonesia. Adapun tujuan dari penulisan artikel ini adalah memberikan gambaran bagaimana praktik belajar mengajar online yang efektif dalam menstimulasi perkembangan anak selama pandemi covid-19 berdasarkan hasil review artikel yang relevan.

\section{METODOLOGI}

Penelitian ini menggunakan metode studi literatur. Studi literatur merupakan kegiatan penelitian menggunakan data hasil dari berbagai studi kepustakaan atau literatur yang relevan dengan permasalahan penelitian yang bersumber dari artikel atau jurnal-jurnal yang relevan. Pencarian literatur menggunakan Google Scholar, dan Z-Library dengan studi literatur periode 2012-2021 berjumlah 55 artikel yang bersumber dari 32 jurnal nasional dan 23 jurnal internasional, untuk di review dalam penulisan literatur ini yang dirasa cocok dengan topik yang peneliti bahas.

Teknik pengumpulan data dengan mengumpulkan sejumlah artikel/jurnal nasional dan internasional yang berkaitan dengan masalah dan tujuan penelitian. Teknik analisis data meliputi pengumpulan sumber data, reduksi data, dan penarikan kesimpulan. Adapun langkah-langkah untuk menganalisis penulisan artikel ini sebagaimana disajikan pada gambar 1 .

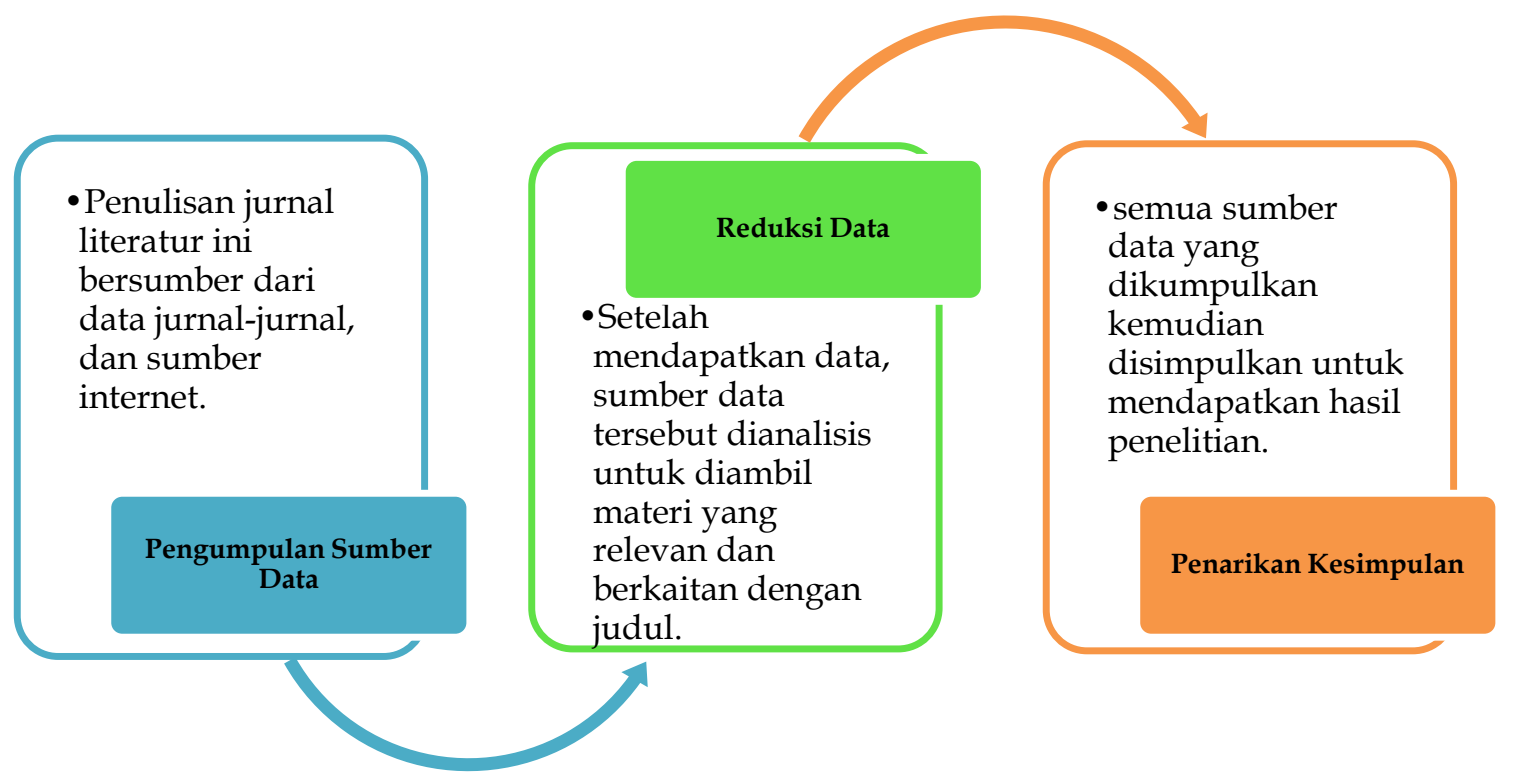

Gambar 1. Langkah-langkah Penelitian

\section{HASIL DAN PEMBAHASAN}

Upaya pencegahan penyebaran covid-19 adalah dengan mengurangi interaksi antar individu dan menghindari perkumpulan secara langsung atau tatap muka. Kebijakan social distancing maupun physical distancing bertujuan untuk meminimalisir penyebaran Covid-19 sehingga mendorong semua elemen pendidikan untuk mengaktifkan kelas secara online. Penutupan sekolah menjadi langkah mitigasi paling efektif untuk meminimalisir penyebaran wabah pada anak-anak. Solusi yang diberikan pemerintah yaitu dengan memberlakukan pembelajaran secara online yang dilakukan di rumah masing-masing dengan memanfaatkan berbagai fasilitas penunjang yang mendukung. Pada artikel ini akan diuraikan praktik belajar mengajar online selama pandemic Covid-19 dari hasil review artikel jurnal yang relevan baik dari jurnal nasional maupun internasional, sebagai berikut: 


\section{Aplikasi Pembelajaran Online di Masa Pandemi Covid-19}

Pendidikan Anak Usia Dini merupakan salah satu jenjang pendidikan yang menerapkan sistem pembelajaran online dimasa pandemi Covid-19. Proses pelaksanaan pembelajaran online pada anak usia dini meliputi: pembelajaran via whatsApp group, pembelajaran melalui tayangan TVRI, zoom, home visit, dan Google Classroom (Anugrahana, 2020; Barrot et al., 2021; Setyowahyudi \& Ferdiyanti, 2020; Sit \& Assingkily, 2020). Adapun perangkat yang dapat digunakan berdasarkan hasil review artikel yang relevan dengan penelitian ini adalah WhatsApp, Google Classroom, Schoology, Edmodo, Rumah Belajar, Ruang Guru, Quipper School, Meja Kita, Icando, IndonesiaX, Google for Education, Kelas Pintar, Microsoft Office 365, Sekolahmu, Zenius, Cisco Webex, Kipin School, Facebook, Youtube, Twitter, maupun Telegram (Djaswadi, 2021b; Suhendro, 2020b; Susanti \& Prameswari, 2020). Berikut diuraikan pelaksanaan pembelajaran anak usia dini.

\section{Pembelajaran Melalui WhatsApp Group}

Whatsapp Group merupakan salah satu aplikasi yang mempunyai berbagai fungsi dalam menyampaikan topik pembelajaran selama masa pandemic covid-19 (Idhayani \& Yunita, 2020). WhatsApp Group merupakan cara yang mudah dan fleksibel bagi guru, anak, dan orangtua, meskipun dibatasi dengan jarak, ruang dan waktu dalam proses pembelajaran, dimana fitur ini hanya dapat dilakukan dengan pesan teks, pesan suara, panggilan video, menerima dan mengirim gambar, video dan dokumen file (Hutami \& Nugraheni, 2020). Selain itu, WhatsApp juga tidak banyak menghabiskan kuota internet dan juga jaringan yang digunakan juga tidak terlalu kuat sehingga yang tinggal di derah terpencil bisa meggunakan WhatsApp dalam proses pembelajaran (Daryani, 2021).

Menurut (Hutami \& Nugraheni, 2020) metode yang dapat digunakan guru di Taman Kanak-Kanak dalam proses pelaksanaan pembelajaran melalui WhatsApp group, adalah: 1) Metode bermain, guru membuat sebuah tutorial, misalnya membuat bendera merah putih, kemudian mengirimkannya di grup. Orangtua dan anak menyiapkan alat dan bahan kemudian anak mengikuti tutorial tersebut dan setelah selesai, hasil di share pada WhatsApp group. 2) Metode bercakap-cakap, guru menggunakan fitur panggilan video di WhatsApp Group untuk bercakap-cakap dengan anak mengenai tata cara menjaga kesehatan pada masa COVID-19. 3) Metode bercerita, guru mengajak anak untuk bercerita tentang kegiatan yang dilakukan dirumah melalui rekaman vidio atau zoom meeting. 4) Metode demonstrasi, guru mengajak anak untuk membuat rumah gadang dengan alat dan bahan yang ada dirumah. Guru mendemokan urutan tata cara membuat rumah gadang. Sesudah selesai mengirimkan fotonya atau vidionya melalui Group WhatsApp. 5) Metode pemberian tugas, adalah guru memberikan lembar kerja kepada anak untuk menirukan tulisan "tanah airku". Setelah selesai menirukan tulisan kemudian mengirimkan hasilnya melalui WhatsApp Group.

\section{Pembelajaran Melalui Tayangan TVRI}

Di Indonesia, salah satu tayangan televisi yang digunakan untuk menyiarkan konten edukasi di masa pandemic covid-19 adalah saluran TVRI (Herliandry et al., 2020). Adapun panduan yang dapat dilakukan oleh orangtua dan anak berdasarkan (Kemendikbud, 2020), adalah sebagai berikut: 1) Sebelum tayangan: 5-10 menit sebelum program ditayangkan, orang tua dapat mengajak anak duduk bersama dengan sikap rileks, menjelaskan sekilas tentang tayangan (apa yang akan ditonton dan tokoh-tokohnya) dan Menyampaikan lamanya tayangan dan aktivitas yang akan dilakukan dengan anak. 2) Saat tayangan: Kegiatan yang dapat dilakukan bersama anak saat tayangan berlangsung adalah bergerak dan bernyanyi. Ajak anak mengikuti gerakan yang dicontohkan tokoh atau menyanyikan lagu-lagu dalam tayangan dan berdialog dengan anak. Lakukan dialog interaktif dengan anak tentang topik yang sedang dibahas. Ajak anak bermain peran mengikuti tokoh cerita. 3) Setelah tayangan: Orang tua dapat mengajak anak melakukan kegiatan alternatif yaitu membacakan Buku Cerita. Selesai kegiatan, lakukan dialog dengan anak tentang ciri, perasaan atau sifat tokoh, 
kejadian yang terjadi, dan lain-lain, bermain imajinatif. Semangati anak untuk membuat cerita melalui gambar atau simbol ciptaan anak dan memintanya menceritakan sambil memperagakan hal yang dilakukan tokoh dalam ceritanya, membuat Proyek Bersama. Ajak anak melakukan percobaan sains sederhana, membuat kue, dll yang membuatnya belajar hal baru, dan merawat Lingkungan. Bersama-sama berkebun, merawat hewan, atau membersihkan rumah dan lingkungan sekitar.

\section{Pembelajaran Melalui Zoom dan Google Clasroom}

Zoom adalah salah satu aplikasi yang digunakan untuk pembelajaran online yang digunakan oleh semua tingkat Pendidikan dimana fitur ini dapat menampilkan proses pembelajaran dalam bentuk suara, video, foto dan dapat berbagi layar untuk melakukan presentasi dalam sebuah kegiatan belajar mengajar (Makhiyah \& Watini, 2021). Aplikasi zoom meetings menyediakan fitur layanan video yang bisa menghubungkan 2 sampai 100 pengguna dalam satu ruang video conference, menyediakan layanan chat serta dilengkapi dengan fitur share scran (Diana et al., 2021). Pembelajaran melalui Zoom Meetings, memudahkan guru dalam menyampaikan bahan ajar dalam pembelajaran online, karena fitur ini dapat menampilkan semua gambar peserta yang mengikuti zoom sehingga guru dapat melihat apa yang dilakukan oleh peserta didik, (Feni, 2021).

Pembelajaran melalui zoom untuk anak TK membutuhkan media pembelajaran karena siswa TK belum menyadari akan pentingnya belajar. Guru harus kreatif dalam membuat tujuan pembelajaran, memilih materi, menentukan pendekatan/metode/media, yang mengacu kepada aspek-aspek perkembangan anak dalam melaksanakan pembelajaran dan menyusun alat evaluasi (Adjie et al., 2020). Adapun cara yang dapat digunakan dalam pembelajaran melalui zoom meeting, pertama-tama mempersiapkan video dan power point untuk menyampaikan materi secara daring melalui zoom meeting, berupa penjelasan materi, video lagu sesuai tema atau video cara pembuatan hasil karya, kemudian dibuat pula power point yang berisi materi yang akan disampaikan dalam pembelajaran daring melalui zoom meeting (Vita et al., 2021).

Metode pembelajaran melalui zoom dapat disesuaikan dengan materi yang akan disampaikan dan tujuan pembelajaran yang hendak dicapai. Metode yang digunakan oleh guru diantaranya metode ceramah, metode diskusi, metode tanya jawab dan metode pengamatan tergantung suasana dan kondisi anak-anak (Feni, 2021).

\section{Pembelajaran Melalui Home Visit}

Program home visit merupakan salah satu program di TK di era new normal. Menurut (Ibda \& Laeli, 2021) kegiatan home visit guru dapat mengurangi sedikit kesulitan yang dialami orang tua dalam pembelajaran daring. Menurut (Nirmala \& Annuar, 2020) home visit menjadi solusi bagi guru TK pada peserta didiknya yang tidak terjangkau koneksi jaringan atau yang tidak memiliki alat untuk belajar daring untuk tetap memberikan layanan yang terbaik pada semua anak didiknya. Menurut (Mumtazah \& Sutama, 2021) proses home visit terdiri dari prencanaan, pelaksanaan, evaluasi, dan analisis hasil evaluasi, tindak lanjut dan terakhir yaitu laporan, sebagai berikut: 1) Perencanaan Program Home Visit Perencanaan: Perencanaan merupakan sebuah proses kegiatan yang dilakukan sebelum pelaksanaan untuk mempersiapkan program tersebut, meliputi: pertama, guru memetakan nama anak dan wali yang akan diikutkan dalam program home visit beserta dengan alamat rumahnya; kedua, pembuatan jadwal dengan batas maksimal satu kali satu jam tatap muka dalam satu minggu saat program home visit; ketiga, pembuatan peraturan untuk mematuhi protokol kesehatan saat program berlangsung; keempat, pembuatan bahan dan materi yang tersusun dalam RPPM terkait aspek perkembangan anak; dan kelima, pembuatan buku jurnal pelaksanaan program home visit. 2) Pelaksanaan Program Home Visit: Pelaksanaan merupakan kegiatan menjalankan sebuah perencanaan sebelumya, meliputi: pertama, melakukan komunikasi untuk konfirmasi ulang dengan wali murid terkait dengan peraturan, dan jadwal; kedua, 
menjalankan program kunjungan rumah dengan perencanaan yang telah dibuat; ketiga, guru memberikan dan menerangkan apa yang akan dilakukan anak Bersama orangtua di rumah sesuai RPPH agar anak yang bersangkutan tidak ketinggalan dengan peserta didik lain; dan yang keempat, jika jam kunjungan selesai maka guru pun mengakhirinya. 3) Evaluasi Program Home Visit: Setiap pertemuan, guru menuliskan evaluasi hasil perkembangan anak yang kemudian dibandingkan dengan hasil di hari sebelumnya. Jika pun perkembangannya selalu dalam peningkatan maka perbandingan itu dibatasi dengan standar tingkat pencapaian perkembangan anak (STPPA). Diskusi yang dilakukan guru dengan orang tua adalah untuk membicarakan tindak lanjut dari program tersebut. Berdiskusi untuk saling terbuka dari permasalahan perkembangan anak. Dikusi untuk saling bertukar ide dan tips di antara sesama wali dalam mengembangakan kemampuan anak. 4) Pelaporan Program Home Visit Pelaporan: Pelaporan hasil perkembangan dibuat oleh guru untuk disampaikan dalam bentuk rapor dan dibagikannya di akhir semesternya. Di dalam buku raport tersebut guru akan menguraikan perkembangan anak.

\section{Hambatan Belajar Mengajar Online}

Pembelajaran online dengan media digital menghadirkan hambatan-hambatan baru bagi pengguna dalam proses belajar mengajar (Emeilia \& Muntazah, 2021). Ketidakmahiran pendidik, peserta didik, dan orang tua dalam mengoperasikan aplikasi pembelajaran online dapat menjadi masalah menuju keefektifan dalam proses belajar mengajar (Nurdin \& Anhusadar, 2020). Berdasarkan review artikel hambatan dalam pembelajaran online hingga kini bagi para pengguna, diantaranya belum mahir mengoperasikan media online secara kreatif (Nurdin \& Anhusadar, 2020), kurangnya peralatan-peralatan yang mendukung keefektifan belajar mengajar, kurangnya koneksi internet di daerah-daerah tertentu (Barrot et al., 2021), kurang maksimalnya waktu dan kemampuan pendampingan selama proses belajar (Mulyawan, 2021), terbatasnya komunikasi antarpribadi, keterbatasan ruang dan waktu dalam aktivitas pembelajaran, ketidakaktifan siswa dalam mengikuti pembelajaran (Emeilia \& Muntazah, 2021).

Menurut Emeilia \& Muntazah (2021) hambatan-hambatan dalam proses pembelajaran online terdiri dari hambatan personal, hambatan kultur dan budaya, hambatan fisik, dan hambatan lingkungan. Hambatan personal mencakup kejenuhan komunikasi, self-confidence dan masalah emosional. Hambatan kultur dan budaya mencakup bahasa, kepercayan dan keyakinan. Hambatan fisik mencakup panggilan telepon, jarak antar individu, dan radio. Hambatan lingkungan mencakup tingkat aktivitas, tingkat kenyamanan, gangguan, dan waktu. Menurut Anugrahana (2020) hambatan-hambatan dalam pembelajaran online, meliputi orangtua tidak bisa diajak kerja sama dalam pendampingan anak saat proses pembelajaran berlangsung, informasi WA tidak selalu langsung diterima wali siswa karena krisis kuota, pemantauan kejujuran siswa dalam mengerjakan evaluasi karena tidak bisa bertatap muka dengan guru, orang tua yang tidak bisa menjelaskan dengan detail kepada siswa, dan guru tidak bisa memantau proses belajar anak secara langsung.

\section{Solusi Belajar Mengajar Online}

Banyaknya tantangan yang ditimbulkan dalam proses pembelajaran online, mengharuskan pihak-pihak terkait memberikan solusi terbaik untuk penangan dari permasalahan tersebut. Berdasarkan review artikel solusi dalam pembelajaran online yang dapat dilakukan oleh tenaga para pendidik adalah membuat program online, LMS, dan media sosial (Juraboyev, 2021); dengan mencari tempat terbaik untuk mendapatkan sinyal yang bermasalah baik guru maupun siswa (Muslimin \& Harintama, 2020); guru melakukan home visit pada peserta didik yang tidak terjangkau jaringan, maupun kepada peserta didik yang tidak memiliki perangkat digital (Sit \& Assingkily, 2020); guru menyiapkan materi pembelajaran disertai dengan video, mengenai keterbatasan penguasaan TI, guru dapat menggunakan platform dengan pengoperasian yang lebih sederhana kepada peserta didik 
seperti WhatsApp, dan bagi siswa yang tidak aktif, guru melakukan via telpon untuk mencari tahu kendala yang dialaminya (Efriana, 2021).

\section{Harapan untuk Pembelajaran Online Paska Covid-19}

Pembelajaran online memberikan banyak tantangan, namun tantangan tersebut dapat diminimalisir dengan berbagai solusi dari pemerintah, guru, maupun pelajar untuk penanganan permasalahan tersebut. Oleh karena itu, pembelajaran online ini diharapkan untuk terus dipertahankan dan ditingkatkan. Menurut Anugrahana (2020) apabila proses belajar mengajar sudah kembali ke cara tradisional atau pembelajaran tatap muka di dalam kelas, sebaiknya pembelajaran online tetap bisa dilaksanakan untuk melatih keterampilan guru dan siswa pada era abad 4.0. selain itu, pembelajaran online juga memberikan kemudahan dalam memberikan transfer informasi pada berbagai situasi dan kondisi (Herliandry et al., 2020).

\section{SIMPULAN}

Praktik belajar mengajar online masih terus berlanjut sehingga perlu adanya gambaran bagaimana proses pembelajaraan dapat menstimulasi perkembangan anak. Hasil review pustaka menunjukan bahwa guru, orangtua dan anak dapat melaksanakan proses pembelajaran melalui beberapa cara, meliputi pembelajaran melalui whatsApp group, home visit, zoom dan google classroom, dan pembelajaran melalui tayangan televisi saluran TVRI. Hasil penelitian ini dapat digunakan sebagai bahan referensi atau acuan dalam mengevaluasi praktik belajar mengajar online, sehingga hambatan yang terjadi pada pembelajaran daring dapat diatasi oleh orang tua, guru, atau stakeholder di dalam dunia pendidikan.

\section{UCAPAN TERIMA KASIH}

Penulis mengucapkan terimakasih kepada dewan editor dan redaksi Jurnal Obsesi yang telah berkenan untuk menerbitkan artikel ini. Penulis juga mengucapkan terimakasih kepada Dr. Muthmainah, S.Pd., M.Pd,, selaku dosen pembimbing dalam penulisan artikel ini.

\section{DAFTAR PUSTAKA}

Abbasi, S., Ayoob, T., Malik, A., \& Memon, S. I. (2020). Perceptions of Students Regarding Elearning During Covid-19 at a Private Medical College. Pak J Med Sci, 36((COVID19-S4)), S57-S61. https://doi.org/10.12669/pjms.36.COVID19-S4.2766

Adjie, N., Putri, S. U., \& Dewi, F. (2020). Peningkatan Kemampuan Koneksi Matematika melalui Pendidikan Matematika Realistik (PMR) pada Anak Usia Dini. Jurnal Obsesi : Jurnal Pendidikan Anak Usia Dini, 5(2), 1325-1338. https://doi.org/10.31004/obsesi.v5i2.846

Agus Susilo, F. (2013). Peningkatan efektivitas pada proses pembelajaran. MATHEdunesa, 2(1).

Anugrahana, A. (2020). Hambatan, solusi dan harapan: Pembelajaran daring selama masa pandemi covid-19 oleh guru sekolah dasar. Scholaria: Jurnal Pendidikan Dan Kebudayaan, 10(3), 282-289. https:// doi.org/10.24246/j.js.2020.v10.i3.p282-289

Barrot, J. S., Llenares, I. I., \& del Rosario, L. S. (2021). Students' online learning challenges during the pandemic and how they cope with them: The case of the Philippines. Education and Information Technologies, 26(6), 7321-7338. https:// doi.org/10.1007/s10639-021-10589-x

Basilaia, G., \& Kvavadze, D. (2020). Transition to online education in schools during a sars-cov-2 coronavirus (covid-19) pandemic in georgia. Pedagogical Research, 5(4). https://doi.org/10.29333/pr/7937

Chang, T. Y., Hsu, M. L., Kwon, J. S., Kusdhany, M. L. S., \& Hong, G. (2021). Effect of online learning for dental education in asia during the pandemic of COVID-19. Journal of Dental Sciences, 16(4), 1095-1101. https://doi.org/10.1016/j.jds.2021.06.006

Crawford, J., Butler-henderson, K., Rudolph, J., Malkawi, B., Glowatz, M., Magni, P. A., \& Lam, S. (2020). Covid-19: 20 countries ' higher education intra-period digital pedagogy responses. Journal of Applied Learning \& Teaching, 3(1). https://doi.org/10.37074/jalt.2020.3.1.7 
Daryani. (2021). Peran Guru dalam Media Pembelajaran Grup WhatsApp di Masa Pandemi Covid 19. Universitas Riau. https://doi.org/10.31219/osf.io/mdsr9

Diana, Jalaluddin, \& Kenedi, A. (2021). Efisiensi Metode Demonstrasi Melalui Zoom Meeting Untuk Meningkatkan Kemampuan Kognitif Siswa Dalam Pembelajaran PAI. Jurnal Mubtadiin, $7(02)$, 1689-1699. http://journal.unilak.ac.id/index.php/JIEB/article/view/3845\%0Ahttp://dspace.uc.ac.i d/handle/123456789/1288

Djaswadi. (2021a). Upaya Peningkatan Kompetensi Guru dalam Menerapkan Pembelajaran Daring Masa Pandemi Covid 19 dapat Meningkatkan Prestasi Belajar Peserta Didik. Journal of Insdustrial Engineering \& Management Research, 2(1), 156-179. https://doi.org/10.36841/consilium.v1i2.1208

Djaswadi. (2021b). Upaya Peningkatan Kompetensi Guru Dalam Menerapkan Pembelajaran Daring Masa Pandemi Covid 19. Journal of Industrial Engineering \& Management Research, 2(1), 156-179. https://doi.org/10.36841/consilium.v1i2.1208

Dong, C., Cao, S., \& Li, H. (2020). Young children's online learning during COVID-19 pandemic: Chinese parents' beliefs and attitudes. Children and Youth Services Review, 118(August), 105440. https://doi.org/10.1016/i.childyouth.2020.105440

Efriana, L. (2021). Problems of online learning during covid-19 pandemic in efl classroom and the solution. JELITA: Journal of English Language Teaching and Literature, 2(1), 2721-1916.

Eickelmann, B., \& Gerick, J. (2020). Lernen mit digitalen Medien. Zielsetzungen in Zeiten von Corona und unter besonderer Berücksichtigung von sozialen Ungleichheiten. "Langsam Vermisse Ich Die Schule ...". Schule Während Und Nach Der Corona-Pandemie., 153-162. https://doi.org/10.31244/9783830992318.09

Emeilia, R. I., \& Muntazah, A. (2021). Hambatan komunikasi dalam pembelajaran online di masa $\begin{array}{llll}\text { pandemi covid-19. } & \text { AKRAB JUARA, }\end{array}$ https://doi.org/10.18196/jas.v2i2.11863

Feni, A. (2021). Penerapan Media Pembelajaran Berbasis Aplikasi Zoom Clouds Meetings dalam Pembelajaran Tematik Kelas I di SD NU Master Sokaraja. http://repository.iainpurwokerto.ac.id/id/eprint/11342

Herliandry, L. D., Nurhasanah, N., Suban, M. E., \& Kuswanto, H. (2020). Pembelajaran pada masa pandemi covid-19. JTP - Jurnal Teknologi Pendidikan, 22(1), 65-70. https://doi.org/10.21009/itp.v22i1.15286

Hodges, C., Moore, S., Lockee, B., Trust, T., \& Bond, A. (2020). The difference between emergency remote teaching and online learning. Educause, 1-12. https://er.educause.edu/articles/2020/3/the-difference-between-emergency-remoteteaching-and-online-learning

Hutami, M. S., \& Nugraheni, A. S. (2020). Metode Pembelajaran melalui Whatsapp Group sebagai Antisipasi Penyebaran Covid-19 pada PAUD di TK ABA Kleco Kotagede. In Paudia: Jurnal Penelitian dalam Bidang Pendidikan Anak Usia Dini (Vol. 9, Issue 1, pp. 126-130). https://doi.org/10.26877/paudia.v9i2.7023

Ibda, H., \& Laeli, D. N. (2021). Hasil Belajar Siswa Saat Pandemi Covid-19 Melalui Home Visit Studi di MI Salafiyah Kranggan. At-Thullab: Jurnal Pendidikan Guru Madrasah Ibtidaiyah, 5(1), 12. https:// doi.org/10.30736/atl.v5i1.451

Idhayani, N., \& Yunita, W. O. N. (2020). Metode Pembelajaran Melalui Whatsapp Group Sebagai Antisipasi Penyebaran Covid-19 Pada AUD Di TK Islam Ummusshabri. Program Studi Pendidikan Guru Pendidikan Anak Usia Dini, Universitas Muhammadiyah Kendari, 9(1), 126-130.

Juraboyev, B. B. U. (2021). Problems and solutions for online teaching and learning of foreign languages. Scientific Journal Impact Factor, 2(2), 127-131.

Kartini, K. (2021). Analisis Pembelajaran Online Anak Usia Dini Masa Pandemi COVID -19 Kota dan Perdalaman. Jurnal Obsesi: Jurnal Pendidikan Anak Usia DiniJurnal Obsesi : Jurnal Pendidikan Anak Usia Dini, 6(2), 809-818. https://doi.org/10.31004/obsesi.v6i2.880

Kemendikbud. (2020). Belajar Dari Rimah Melalui TVRI. https://doi.org/10.23917/profetika.v21i1.11719 
König, J., Jäger-Biela, D. J., \& Glutsch, N. (2020). Adapting to online teaching during Covid-19 school closure: Teacher education and teacher competence effects among early career teachers in Germany. European Journal of Teacher Education, 43(4), 608-622. https://doi.org/10.1080/02619768.2020.1809650

Kumar, V., \& Nanda, P. (2019). Social media in higher education: A framework for continuous engagement. International Journal of Information and Communication Technology Education, 15(1), 109-120. https:/ / doi.org/10.4018/IJICTE.2019010108

Kusuma, J. W., \& Hamidah, H. (2020). Perbandingan hasil belajar matematika dengan penggunaan platform whatsapp group dan webinar zoom dalam pembelajaran jarak jauh pada masa pandemik covid 19. JIPMat, 5(1). https://doi.org/10.26877/jipmat.v5i1.5942

Law, M. Y. (2021). Student's attitude and satisfaction towards transformative learning: A research study on emergency remote learning in tertiary education. Creative Education, 12(03), 494528. https:// doi.org/10.4236/ce.2021.123035

Makhiyah, A., \& Watini, S. (2021). Efektifitas Penggunaan Aplikasi Zoom pada Masa Pandemi dalam Pengembangan Aspek Kognitif. Jurnal Pendidikan Tambusai, 5(2), 4238-4246.

Moore, J. L., Dickson-Deane, C., \& Galyen, K. (2011). E-Learning, online learning, and distance learning environments: Are they the same? Internet and Higher Education, 14(2), 129-135. https://doi.org/10.1016/j.iheduc.2010.10.001

Mulyawan, U. (2021). Problematika online learning: Hambatan pembelajaran bahasa inggris siswa. Jurnal Ilmiah Hospitality, 9(2), 301-308. https://doi.org/10.47492/jih.v9i2.349

Mumtazah, D., \& Sutama, S. (2021). Program Home Visit: Penguatan Perkembangan Nilai Agama dan Moral Anak Usia Dini di Era New Normal. Golden Age: Jurnal Ilmiah Tumbuh Kembang Anak Usia Dini, 6(1), 37-46. https://doi.org/10.14421/jga.2021.61-04

Muslimin, A. I., \& Harintama, F. (2020). Online learning during pandemic: Students' motivation, challenges, and alternatives. Loquen: English Studies Journal, 13(2), 60. https:// doi.org/10.32678/loquen.v13i2.3558

Napitupulu, C. A., Ananda, K., Praticia, R., \& Rahmadini, V. W. (2020). Implementasi Pembelajaran Kolaboratif Daring (Online Collaborative Learning) Dalam Rangka Pembentukan Dukungan Sosial Mahasiswa PG PAUD FKIP Universitas Palangka Raya. Jurnal Pendidikan Dan Psikologi Pintar Harati, 16(2), 1-17.

Negara, I. M. (2018). Students perception: The use of google classroom in teaching-learning process. Jurnal Ilmiah STBA, 4(1).

Nirmala, B., \& Annuar, H. (2020). Home Visit: Strategi PAUD dari Rumah bagi Guru di Daerah 3T pada Masa Pandemi Covid-19. Jurnal Obsesi : Jurnal Pendidikan Anak Usia Dini, 5(2), 1052-1062. https://doi.org/10.31004/obsesi.v5i2.716

Noori, A. Q. (2021). The impact of COVID-19 pandemic on students' learning in higher education in Afghanistan. Heliyon, 7(10), e08113. https:// doi.org/10.1016/j.heliyon.2021.e08113

Nurdin, N., \& Anhusadar, L. (2020). Efektivitas pembelajaran online pendidik paud di tengah pandemi covid 19. Jurnal Obsesi: Jurnal Pendidikan Anak Usia Dini, 5(1), 686. https://doi.org/10.31004/obsesi.v5i1.699

O'Doherty, D., Dromey, M., Lougheed, J., Hannigan, A., Last, J., \& McGrath1, D. (2018). Barriers and solutions to online learning in medical education: An integrative review diane. BMC Medical Education, 18(130), 832-834. https:// doi.org/10.1186/s12909-018-1240-0

Oktavian, R., \& Aldya, R. F. (2020). Efektivitas pembelajaran daring terintegrasi di era pendidikan 4.0. Didaktis: Jurnal Pendidikan Dan Ilmu Pengetahuan, 20(2), 129-135. https://doi.org/10.30651/didaktis.v20i2.4763

Orfan, S. N., \& Elmyar, A. H. (2020). Public knowledge, practices and attitudes towards covid-19 in afghanistan. Public Health of Indonesia, 6(4), 104-115. https://doi.org/10.36685/phi.v6i4.356

Safrizal, S., Yulia, R., \& Suryana, D. (2021). Difficulties of Implementing Online Learning in Kindergarten During the Covid-19 Pandemic Outbreak: Teacher's Perspective Review. Jurnal Pendidikan Dan Pengajaran, 54(3), 406. https:// doi.org/10.23887/jpp.v54i3.34974

Setyowahyudi, R., \& Ferdiyanti, T. (2020). Keterampilan Guru PAUD Kabupaten Ponorogo Dalam Memberikan Penguatan Selama Masa Pandemi COVID-19. Jurnal Golden Age, 4(01), 100111. https://doi.org/10.29408/jga.v4i01.2167 
DOI: 10.31004/obsesi.v6i4.2228

Sit, M., \& Assingkily, M. S. (2020). Persepsi Guru tentang Social Distancing pada Pendidikan AUD Era New Normal. Jurnal Obsesi : Jurnal Pendidikan Anak Usia Dini, 5(2), 1009-1023. https://doi.org/10.31004/obsesi.v5i2.756

So, S. (2016). Mobile instant messaging support for teaching and learning in higher education. Internet and Higher Education, 31, 32-42. https://doi.org/10.1016/j.iheduc.2016.06.001

Suhendro, E. (2020a). Strategi Pembelajaran Pendidikan Anak Usia Dini di. Golden Age: Jurnal Ilmiah Tumbuh Kembang Anak Usia Dini, 5(September), 133-140. https://doi.org/10.14421/iga.2020.53-05

Suhendro, E. (2020b). Strategi Pembelajaran Pendidikan Anak Usia Dini di Masa Pandemi Covid19. Golden Age: Jurnal Ilmiah Tumbuh Kembang Anak Usia Dini, 5(3), 133-140. https://doi.org/10.14421/iga.2020.53-05

Suhendro, E., \& Syaefudin, S. (2020). Nilai-Nilai Kemanusian Dalam Pendidikan Anak Usia Dini Inklusi. JEA (Jurnal Edukasi AUD), 6(1), 1. https:// doi.org/10.18592/jea.v6i1.3430

Sun, L., Tang, Y., \& Zuo, W. (2020). Coronavirus pushes education online. Nature Materials, 19(6), 687. https://doi.org/10.1038/s41563-020-0678-8

Susanti, D. I., \& Prameswari, J. Y. (2020). Adaptasi Blended Learning di Masa Pandemi COVID-19 untuk Pembelajaran Bahasa Inggris di Sekolah Dasar. Lingua Susastra, 1(2), 50-61. https://doi.org/10.24036/1s.v1i2.8

Thanji, M., \& Vasantha, S. (2016). ICT factors influencing consumer adoption of e-commerce offerings for education. Indian Journal of Science and Technology, 9(32). https://doi.org/10.17485/ijst/2016/v9i32/98650

Van Schagen Johnson, A., La Paro, K. M., \& Crosby, D. A. (2017). Early practicum experiences: Preservice early childhood students' perceptions and sense of efficacy. Early Childhood Education Journal, 45(2), 229-236. https://doi.org/10.1007/s10643-016-0771-4

Vita, A., Rezeki, T., Amelia, D., Nuraeni, E., \& Dewi, F. (2021). Implementasi Penggunaan Aplikasi Zoom Meeting dalam Pembelajaran Daring di TK Kemala Bhayangkari 11 Purwakarta. IJOCSEE: Indonesian Journal of Community Services in Engineering and Education, 1(1), 56-64.

Widiastuti, Y. K. W., Rasmani, U. E. E., \& Wahyuningsih, S. (2020). Mengkaji Penerapan E-Learning pada Anak Usia Dini. Jurnal Obsesi : Jurnal Pendidikan Anak Usia Dini, 5(2), 1240-1247. https://doi.org/10.31004/obsesi.v5i2.752 